\title{
Spatiotemporal distribution of the benthic macrofauna in an urbanized subtropical estuary: environmental variations and anthropogenic impacts
}

\author{
Pedro Rocha Mattos ${ }^{1 *}$, Tito César Marques de Almeida ${ }^{1}$ \\ ${ }^{1}$ Universidade do Vale do Itajaí-UNIVALI. \\ (Rua Uruguai, 458, Centro Bloco D2 Sala 144 Caixa Postal 360, CEP 8302-202, Itajaí, SC, Brazil.) \\ *Corresponding author: pedrormattos@gmail.com
}

\begin{abstract}
This study was conducted in the Itajaí-Açu river lower estuary in Southern Brazil, in which we aimed to: (1) analyze spatiotemporal variations on the macrofauna; (2) search for relationships between environmental variables and the assembly and (3) evaluate the influence of capital dredging upon the assembly. Two hundred twenty eight samples were performed in four stations, two of which affected by dredging. Sediment (sand, silt and clay, organic matter and carbonate) and water column's variables (temperature, salinity, $\mathrm{pH}$, dissolved oxygen, and turbidity) were also assessed. We applied Principal Component Analysis for environmental variables and Hierarchical Clustering for biotic data. Correlations between environmental and biotic matrices were tested by Canonical Analysis of Principal Coordinates. Spatiotemporal variations in the assembly were tested by Permutational Multivariate Analysis of Variance. From the 21.839 organisms sampled, 97\% was represented by the gastropod Heleobia australis. Despite the influence of the river discharge on the ecosystem, dredging was deleterious to the assembly, favoring opportunistic organisms such as H. australis.
\end{abstract}

Descriptors: Estuaries, Macrofauna, Dredging, River discharge.

\section{RESUMo}

Este estudo foi conduzido no baixo estuário do rio ItajaíAçu, sul do Brasil, no qual buscamos: (1) determinar a distribuição espaço-temporal da macrofauna (2) relacionar o padrão de distribuição da assembleia com as variáveis ambientais e (3) avaliar a influência das dragagens de aprofundamento sobre a estrutura e composição da assembleia. Duzentas e vinte e oito amostras foram coletadas em quatro estações localizadas no baixo estuário, duas delas afetadas pelas dragagens. A composição do sedimento (areia, silte e argila, matéria orgânica e carbonato) as variáveis da coluna de água (temperatura, salinidade, $\mathrm{pH}$, oxigênio dissolvido e turbidez) também foram analizadas. Utilizou-se de Análise em Componentes Principais para avaliar a variação espaço-temporal das forçantes ambientais, e Agrupamento Hierárquico para a distribuição da assembleia. Correlações entre a matriz de variáveis ambientais e a estrutura multivariada da macrofauna foram testadas por meio da Análise Canônica de Coordenadas Principais. Testamos as variações espaço-temporais das associações por meio de Análise de Variância Multivariada Permutacional. Dos 21.839 organismos coletados, 97\% correspondeu ao gastrópode Heleobia australis. Apesar da descarga fluvial mostrar-se uma importante variável reguladora do ecossistema, as dragagens de aprofundamento foram deletérias à macrofauna, favorecendo a dominância de organismos oportunistas tais como H. australis.

Descritores: Estuários, Macrofauna, Dragagens, Descarga fluvial. 


\section{INTRODUCTION}

Estuaries are responsible for a variety of ecological services such as nutrient cycling, food production and biologic control besides providing habitat for many species. The average global value of annual ecosystem services related to estuaries were estimated in US\$ 22.832,00/ha/year (CONSTANZA et al., 1997), enforcing the importance of their conservation. It is of great concern that estuarine areas are vulnerable to disturbances such as variations in salinity, high organic matter input and anoxic sediment (ROSA; BEMVENUTI, 2006), which can be associated to anthropic impacts.

Due to their geographical features, estuaries worldwide have historically shown to favor human settlement and great urban centers tend to develop in those areas. As a downside of urbanization, population growth and economic development of coastal areas have been menacing the ecological integrity of many estuaries around the globe. We can outline port facilities and dredging operations as some of the main anthropic activities that may inflict damage to estuaries (KENNISH, 2002).

The development of many coastal regions depends on the quality and capacity of its ports to keep with international standards. Because of the shallowness of most estuaries, there is the necessity of permanent dredging of the river bed leading access to the port facilities, in order to make a clear and safe way for large ships.

On the other hand, it is known that dredging not only removes sediment, but considerably alters the macrofaunal assembly inhabiting dredged areas (e.g. STRICKNEY; PERLMUTTER, 1975; NEWELL et al., 2004; COOPER et al., 2011) and disposal sites (e.g. BOLAN; REES, 2003; VIVAN et al., 2009).

Dredging can modify soft bottom habitats, compromising ecosystem biodiversity and functionality (SKILLETER et al., 2006) and the impacts associated to dredging include alterations in the structure and composition of benthic assembly, favoring the dominance of opportunistic organisms. The impacts related to dredging and recovery times of the macrofauna are highly variable (HARVEY et al., 1998) and resilience times can last from a few months (CRUZ-MOTA; COLLINS, 2004) to more than a decade after the disturbances (FRASER et al., 2006).

Now days, most of the literature concerning the impacts of soft-bottom dredging is focused on maintenance dredging and disposal sites. Less attention is been given to impacts inflicted by capital dredging at dredged sites (WARE et al., 2010).
The soft-bottom macrofauna is fundamental for maintaining aquatic ecosystems, as they play an important role in sediment stability, organic matter cycling and turbidity control, besides being an important source of food for larger organisms, many of which are of considerable economic value (THRUSH; DAYTON, 2002). For example, the gastropod Heleobia australis (D'Órbigny, 1835) is one of the main food sources of estuarine fish commercially exploited in southern Brazil (BEMVENUTI, 1997). The tanaid Monokalliapseudes schubarti (GUTU 2006) is abundant in subtropical estuaries, and is consumed by many species of birds and fish (FREITAS-JÚNIOR et al., 2013). Polychaetes are also abundant in subtropical estuaries, acting as an important part of the trophic web (FAUCHALD; JUMARS, 1979; PAGLIOSA; BARBOSA, 2006; SANTI; TAVARES, 2009).

The Itajaí-Açu river estuary in Southern Brazil is one of the greatest urban centers along the coast of the Santa Catarina state sheltering one of the largest port complexes in the country and also many fish processing industries (PEREIRA, 2003). The main sources of pollution of the river are sanitary waste, garbage and industrial wastewater mainly from textile, metallurgy and galvanoplastic industries spread around the water basin (PEREIRAFILHO et al., 2010).

Dredging of the Itajaí-Açu river channel has occurred since 1835 , although the operations became more intense with the increase in maritime commerce in the 1960's (CARVALHO, 1996). The first dredging to deepen the navigation channel occurred in 1978 and successive events took place in 1983, 1996, and 2006 while maintenance dredging since 2000 has been removing around $2 \times 10^{6} \mathrm{~m}^{3}$ per year (INPH, 2012). Although the estuary has been target of several environmental researches throughout the years, only a few aimed to analyze the impacts of dredging operations on the benthic assemblages, such as VIVAN et al. (2009).

In spite of the above mentioned, the present study evaluated the impacts of a capital dredging that took place in 2011, altering the depth of the navigation channel from $-12 \mathrm{~m}$ to $-14 \mathrm{~m}$ removing around $8 \times 10^{6} \mathrm{~m}^{3}$ of sediment. Our goals were to: (1) determine the spatio-temporal distribution of the macrofaunal assembly inhabiting the low Itajaí-Açu river estuary, (2) to relate the distribution pattern to the environmental variables and (3) to evaluate the influence of capital dredging upon the structure and composition of the assembly. 


\section{MATERIAL AND METHODS}

\section{STUDY AREA}

The Itajaí-Açu river estuary is located on a coastal plain, being characterized as salt wedge type. Monthly average river discharge is around $230 \mathrm{~m}^{3} / \mathrm{s}$, and tide pattern is mixed semi-diurnal, with average interval of $0.8 \mathrm{~m}$ (SCHETTINI, 2002). The Itajaí-Açu River represents $90 \%$ of the freshwater input to the estuary, draining a $15500 \mathrm{~km}^{2}$ water basin (PEREIRA-FILHO et al., 2010). Climate at the low estuary can be defined as moist-subtropical, characterized by evenly distributed rainfall along the year and average air temperature above $18^{\circ} \mathrm{C}$ (GAPLAN, 1986).

\section{DATA COLLECTION AND SAMPLING DESIGN}

We established four sampling stations along the low estuary with $1500 \mathrm{~m}$ spacing, two of which were established upstream from the port complex and were not dredged (station 1: 26 $6^{\circ} 33^{\prime} 11.4$ 'S; 48 41 '02.62'”W and station 2 : $26^{\circ} 53^{\prime} 25.51^{\prime \prime} \mathrm{S}$; $48^{\circ} 40^{\prime} 04.62^{\prime \prime} \mathrm{W}$ ) the other two corresponded to the dredged navigation channel (station 3: $26^{\circ} 53^{\prime} 58.6^{\prime \prime} \mathrm{S}$; 48 39'41.26' 'W and station 4: 2654'31.07"S; 48³9'4.68"W). All sampling stations were located on urbanized areas, virtually deprived of riparian vegetation (Figure 1).

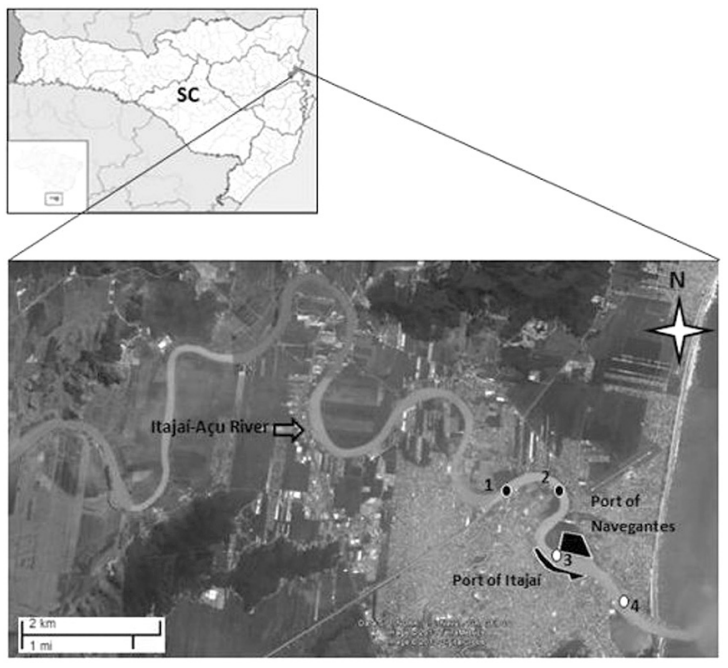

Figure 1. Study area and the sampling stations (1-4) along the low estuary. Stations 1 and 2 were located upstream from the port area and were not dredged while stations 3 and 4 were amidst the dredged area.

A total of 19 monthly sampling campaigns were conducted from December 2010 to October 2012, although there was no sampling effort from January 2011 to April
2011 due to technical issues. Capital dredging occurred from May 2011 to December 2011 except for September 2011 when a major flood interrupted the operations.

Thus for the statistical analysis we considered two fixed and orthogonal factors: station (4 levels) and time (19 levels) (Figure 2), in order to test the null hypothesis of no spatio-temporal differences in the assemblages of dredged and non-dredged stations.

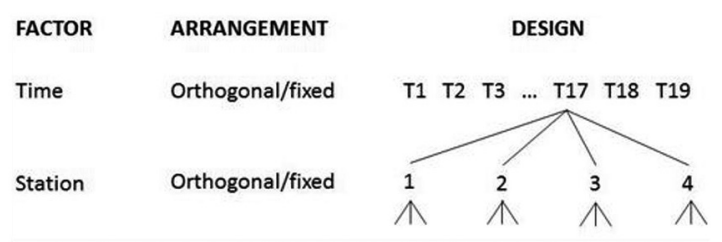

Figure 2. Sampling design totalizing 228 samples. Stations 1 and 2 were located upstream from the port area and were not dredged while stations 3 and 4 were amidst the dredged area.

Sampling was conducted in triplicates, for a total of 228 samples. We used a $0.042 \mathrm{~m}^{2}$ Van-Veen grab for all samples.

Sampled organisms were washed through $0.5 \mathrm{~mm}$ mesh sieves. Retained individuals were fixed in $4 \%$ formalin solution and preserved in $70 \%$ ethanol. Sorting and identification were conducted with a stereoscopic microscope.

A fourth sample was performed at each station/ time for granulometric analysis, performed according to Suguio (1973). Sediment composition was expressed by the percentages of sand, silt and clay (mud), organic matter and carbonate.

Data for temperature $\left({ }^{\circ} \mathrm{C}\right)$, salinity, $\mathrm{pH}$, dissolved oxigen (mg/L) and turbidity (NTU) were measured with a Mulatiparameter Water Quality Sonde YSI 6600 V2 ${ }^{\mathrm{TM}}$, and river discharge data were courtesy from the National Agency of Electric Energy (ANEEL), and expressed as monthly average $\mathrm{m}^{3} / \mathrm{s}$.

\section{DATA ANALYSIS}

We conducted a Principal Components Analysis (PCA) for abiotic data, in order to analyze its spatiotemporal variation. The variables organic matter and carbonate were eliminated from the PCA, since they showed high positive colinearity with mud percentages. The variable sand showed high negative colinearity to the mud percentages and was also excluded from the PCA. Because of its high asymmetry, turbidity data was transformed by $\log 10(x+1)$, and the subsequent matrix 
was normalized by the standard deviation (CLARKE; WARWICK, 1994; CLARKE; GORLEY, 2006).

The structure of the macrofauna was represented by the average and associated standard-error of the indicators of abundance $(\mathrm{N})$ and species richness $(\mathrm{S})$ through space and time.

For similarity analysis, we eliminated all taxa with relative abundance lower than $0.01 \%$. The Bray-Curtis coefficient (CLARKE; GORLEY, 2006) was used to calculate similarities among the abundances $(\log 10(\mathrm{x}+1)$ transformed), and a Permutational Multivariate Analysis of Variance (PERMANOVA) was applied on the resulting resemblance matrix, considering the two factors previously described. For the interpretation of significances, we considered permutation $p$-values, as the permutation number (9999) was considered high (ANDERSON, 2005).

Aiming to visualize patterns of spatio-temporal variation among similarities of macrofauna composition, we performed a Hierarchical Clustering analysis (CLUSTER) applied on the above described resemblance matrix.

Also, in order to identify the main species responsible for the separation of groups evidenced by the CLUSTER diagram, we performed a Similarity Percentages analysis (SIMPER), only considering the taxa which contributed for the accumulated dissimilarity of $90 \%$.

At last, we evaluated the correlation between the biotic and abiotic matrices through Canonical Analyses of Principal Coordinates (CAP). Significances of correlations were tested through 9999 permutations (ANDERSON, 2005).

All analyses were performed using the PRIMER $6^{\circ}$ version 6.1.11 and PERMANOVA $+{ }^{\circ}$ version 1.0.1 softwares.

\section{RESULTS}

\section{ABIOTIC VARIABLES}

Temperature showed a seasonal pattern, ranging from $17^{\circ} \mathrm{C}$ in August 2011 to $24^{\circ} \mathrm{C}$ in January 2012 (Figure 3a).

Average overall salinity considering all sampling stations was 27.4 with a gradient of increasing salinity towards the river mouth, and was reduced in all stations during the flood event in September 2011. Maritime influence was strongest at stations 3 and 4, and in January 2012 there was a great drop in salinity at station 1 (Figure $3 b)$.
Dissolved oxigen and turbidity followed the river discharge trend. At station 4, turbidity was higher during dredging, mainly in October 2011 (Figure 4c and Figure 4d).

The $\mathrm{pH}$ showed a gradient of variation similar to that observed for salinity, with higher values towards the river mouth and raging from 5 to 8 throughout the study (Figure 4e).

River discharge showed great oscillation in short periods of time, ranging from $1348 \mathrm{~m}^{3} / \mathrm{s}$ in September 2011 to $68.5 \mathrm{~m}^{3} / \mathrm{s}$ in March 2012 and with an overall average of $325.7 \mathrm{~m}^{3} / \mathrm{s}$. River discharge was higher than $400 \mathrm{~m}^{3} / \mathrm{s}$ (which we considered intense river discharge) in December 2010, July, August and September 2011 (Figure 4f).

With relation to the sediment variables (sand, mud, organic matter and carbonate) there was considerable fluctuation throughout the study, without a clear pattern.

Sand percentage was above $50 \%$ during dredging at stations 3 and 4, while stations 1 and 2 showed higher content of sand during the flood event (Figure 5a). The percentages of mud behaved inversely, becoming higher at stations 3 and 4 during the flood (Figure 5b).

Carbonate and organic matter followed the same trend observed for mud, although never counting for more than $20 \%$ of sediment composition.

The two first axes of the PCA explained $71.9 \%$ of the variation among samples. Salinity, $\mathrm{pH}$ and dissolved oxygen had the strongest weight in the formation of axis 1 which explained $50.7 \%$ of total variation. Temperature had the strongest weight in the formation of axis 2 which explained $21.2 \%$ of total variation (Table 1 ). Overall, the ordination of samples evidenced the effect of river discharge along axis 1, with samples from December 2010, August 2011 and September 2011 (river discharge greater than $400 \mathrm{~m}^{3} / \mathrm{s}$ ) showing lower salinity and $\mathrm{pH}$. The increase in turbidity and dissolved oxygen during those periods corroborates that suggestion. Along axis 2 we could notice the effect of seasonality upon the environmental variables, with lower temperatures associated to colder months. Along axis 2 it was also possible to notice the effect of dredging, with a tendency of coarser sediment and elevated turbidity during the operations (Figure 5).

\section{BIOTIC VARIABLES}

A total of 21839 organisms were sorted and identified throughout the study, distributed among 5 phylum and 6 classes. Gastropoda was the most abundant group while Polychaeta was the one with higher species richness (Table 2). 

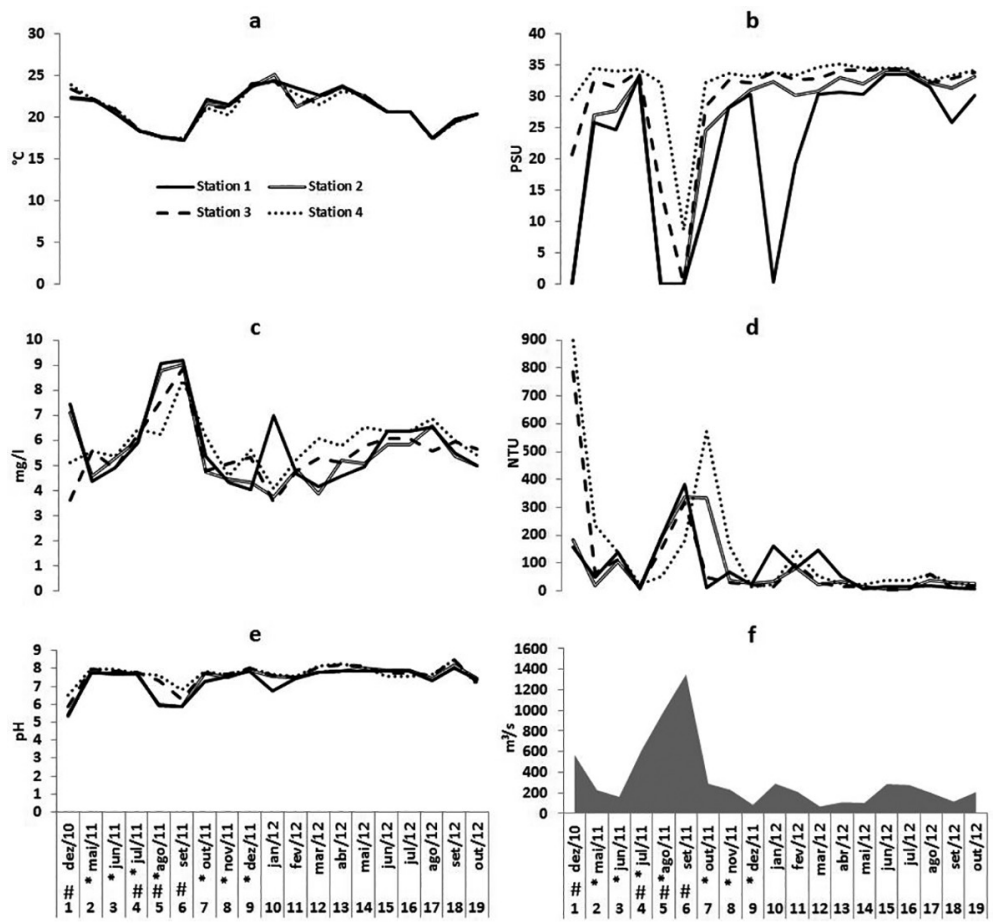

Figure 3. Environmental variables and river discharge along the sampling stations. Stations 1 and 2 were located upstream from the port area and were not dredged while stations 3 and 4 were amidst the dredged area. $a=$ temperature, $b=$ salinity, $c=$ dissolved oxigen, $d=$ turbidity and $e=$ river discharge. * indicates capital dredging while \# indicates river discharge above $400 \mathrm{~m}^{3} / \mathrm{s}$.
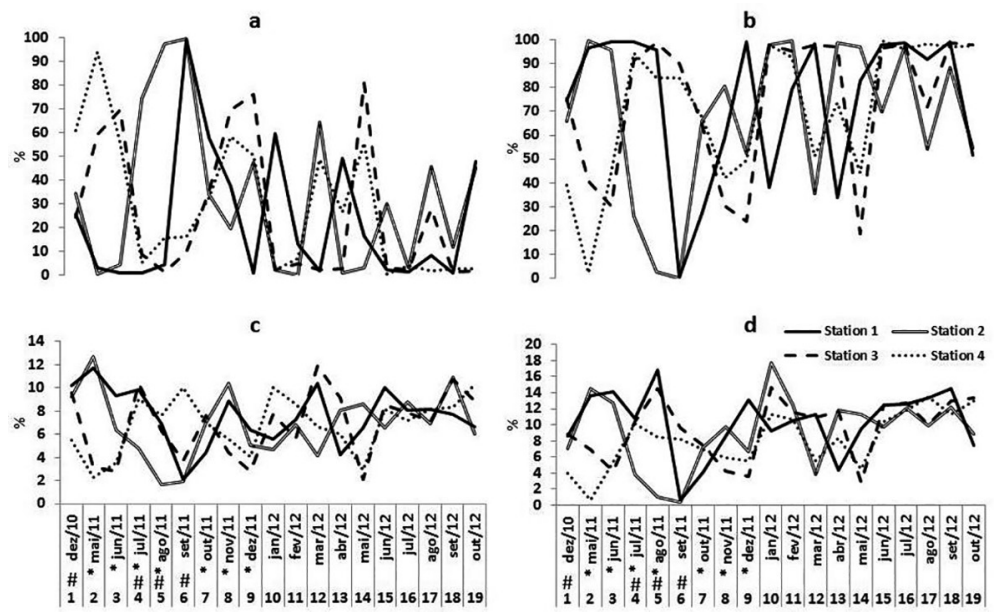

Figure 4. Sediment composition along the sampling stations. $a=$ sand; $b=$ silt/clay; $c=$ carbonate; $d=$ organic matter. *indicates capital dredging while \# indicates river discharge above $400 \mathrm{~m}^{3} / \mathrm{s}$. Stations 1 and 2 were located upstream from the port area and were not dredged while stations 3 and 4 were amidst the dredged area.

The gastropod Heleobia australis (D’Órbigny, 1835) accounted for almost $90 \%$ of all sampled organisms. Other representative taxa were the annelids Heteromastus similis (Southern, 1921) (1\%), Nephtys fluviatilis (Monro, 1937) (1\%), Boccardiella ligerica (Ferronière, 1898) (3,9\%) and the tanaid Monokalliapseudes shcubarti (Gutu, 2006) $(1,7 \%)$.
The greatest total relative abundance $(30.6 \%)$ was observed at station 4 , close to the river mouth while the lowest was observed at station $3(17.2 \%)$. Stations 1 and 2 (upstream from the port facility) showed similar total relative abundances $(26.8 \%$ and $25.2 \%$, respectively).

Overall, the species richness (S) showed higher average values from April to July 2012 at all sampling stations. 


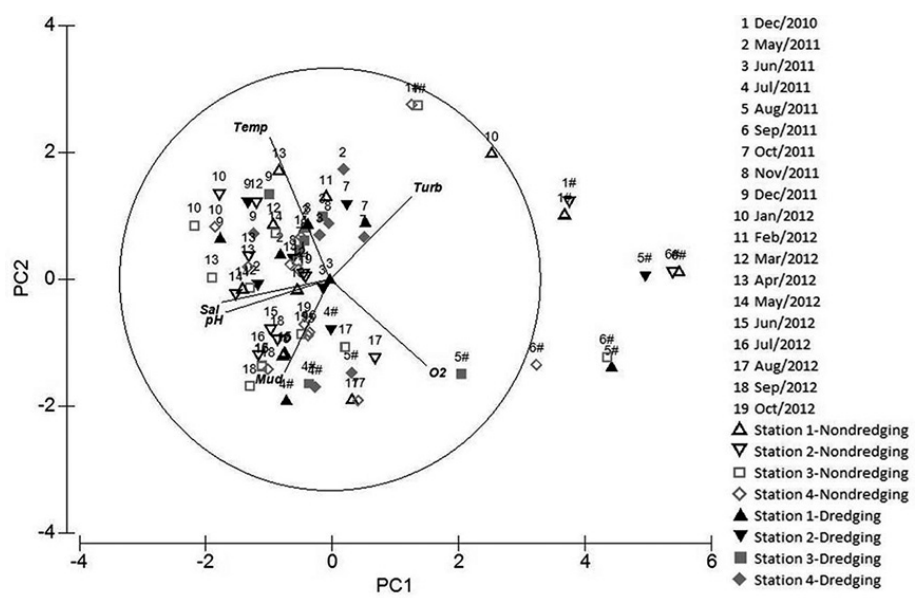

Figure 5. Principal Components Analysis (PCA). Salinity, $\mathrm{pH}$ and dissolved oxigen had the strongest weight in the formation of axis 1 which explained $50.7 \%$ of the distribution of samples. Temperature had the strongest weight in the formation of axis 2 which explained $21.2 \%$ of the variation. Stations 1 and 2 were located upstream from the port area and were not dredged while stations 3 and 4 were amidst the dredged area. Temp=temperature, Turb=turbidity, Sal=salinity, Mud=silt and clay, O2=dissolved oxigen and \# means river discharge above $400 \mathrm{~m}^{3} / \mathrm{s}$. The filled symbols represent dredging activity.

Table 1. Environmental variables and respective correlations to the principal components of the PCA, which explained $71.9 \%$ of the distribution of samples.

\begin{tabular}{lcc}
\hline Variable & PC1 & PC2 \\
\hline Temp & 0.286 & 0.674 \\
Sal & 0.515 & -0.109 \\
$\mathrm{O} 2$ & -0.458 & -0.407 \\
$\mathrm{pH}$ & 0.498 & -0.157 \\
Turb & -0.386 & 0.39 \\
Mud & 0.215 & -0.439 \\
\hline
\end{tabular}

Temp: Temperature, Sal: Salinity, O2: Dissolved oxygen, Turb: Turbidity, Mud: silt and clay.

The greatest richness was observed at station 1 with about 10 species in April 2012. Richness was reduced at stations 1 and 2 when river discharge was above $400 \mathrm{~m}^{3} / \mathrm{s}$, although stations 3 and 4 appeared to be more drastically affected coinciding with dredging activity. Station 3 showed the lowest values of species richness after 13 months of post dredging surveys, with an average number lower than 4 (Figure 6).

With relation to average density $(\mathrm{N})$ we observed great variation at the monthly scale. Maximum density was recorded at station 4 in October 2012, with around $1400 / 0.042 \mathrm{~m}^{2}$. Excluding that period of time, average density was higher at stations 1 and 2 . All stations showed lower densities when river discharge was above $400 \mathrm{~m}^{3} / \mathrm{s}$ and also during dredging operations, although stations 1 and 2 had more prominently peaks of abundance and richness after the disturbances (Figure 6).
The PERMANOVA indicated significance for factors station and time, as well as for the interaction of factors, indicating different temporal variation at each sampled station (Table 3). The diagram obtained through CLUSTER analysis corroborated the PERMANOVA results.

Two groups (I and II) were clear after the analysis. Group I was characterized mostly by samples taken during the dredging activity. Except from time 9 all samples from the dredged stations 3 and 4 during the operations belong to group I. Stations 1 and 2 had three times more samples taken during the dredging allocated at group II. With relation to river discharge, all sampling stations had the majority of samples taken during river discharge above $400 \mathrm{~m} / \mathrm{s}$ allocated in group I (Figure 7).

The SIMPER analysis showed an average dissimilarity of $95.35 \%$ between groups I and II, and seven species contributed to $90.32 \%$ of that dissimilarity. Group I had a greater abundance of $N$. fluviatlis and lowest numbers for the other six species. Group II had lower abundance of $N$. fluviatlis and greater abundance of the other species compared to group II, specially H. australis, which showed the higher dissimilarity between the groups and also the highest dissimilarity/standard deviation ratio (Table 4).

\section{BIOTIC/ABIOTIC INTERACTION}

The CAP analysis evidenced significant correlations between the biotic and abiotic matrices $(p=0,0002)$. The two first canonical correlations were 0.63 and 0.42 and the canonical axes explained $73 \%$ of the distribution of samples. 
Table 2: Relative abundance (\%) along the four sampling stations (1-4). Bold* taxa were selected to statistical analysis.

\begin{tabular}{|c|c|c|c|c|c|c|c|c|c|c|c|}
\hline Taxa & 1 & 2 & 3 & 4 & Total & Taxa & 1 & 2 & 3 & 4 & Total \\
\hline $\begin{array}{l}\text { Alitta succinea } \\
\text { (Leuckart, 1947)* }\end{array}$ & 0.018 & 0.037 & 0.000 & 0.041 & 0.096 & $\begin{array}{c}\text { Heteromastus } \\
\text { similis } \\
\text { (Southern, 1921)* }\end{array}$ & 0.339 & 0.302 & 0.060 & 0.270 & 0.971 \\
\hline Ampharetidae & 0.000 & 0.000 & 0.000 & 0.005 & 0.005 & $\begin{array}{c}\text { Kinbergonuphis } \\
\text { difficilis } \\
\text { (Fauchald, 1982)* }\end{array}$ & 0.009 & 0.041 & 0.000 & 0.124 & 0.174 \\
\hline $\begin{array}{l}\text { Anomalocardia } \\
\text { brasiliana (Gmelin, } \\
1791)^{*}\end{array}$ & 0.307 & 0.092 & 0.014 & 0.037 & 0.449 & $\begin{array}{c}\text { Laeonereis acuta } \\
\text { (Treadwell, 1923)* }^{\text {Tread }}\end{array}$ & 0.000 & 0.023 & 0.000 & 0.009 & 0.032 \\
\hline Aricidea sp. * & 0.041 & 0.005 & 0.018 & 0.165 & 0.229 & Littorinidae & 0.000 & 0.005 & 0.000 & 0.000 & 0.005 \\
\hline $\begin{array}{l}\text { Armandia hossfeldi } \\
\text { (Hartman-Schroeder, } \\
\text { 1956)* }\end{array}$ & 0.005 & 0.005 & 0.005 & 0.014 & 0.027 & Lumbrineridae & 0.009 & 0.000 & 0.000 & 0.000 & 0.009 \\
\hline Boccardia sp. * & 0.023 & 0.032 & 0.005 & 0.133 & 0.192 & Magelona sp. & 0.000 & 0.000 & 0.000 & 0.009 & 0.009 \\
\hline $\begin{array}{l}\text { Boccardiella ligerica } \\
\text { (Ferronière, 1898)* }\end{array}$ & 0.119 & 1.167 & 0.005 & 2.591 & 3.882 & $\begin{array}{l}\text { Monokalliap- } \\
\text { seudes shubarti } \\
(\text { Gutu, 2006)* }\end{array}$ & 0.700 & 0.916 & 0.014 & 0.064 & 1.694 \\
\hline Brachyura & 0.000 & 0.000 & 0.005 & 0.005 & 0.009 & Natica sp. * & 0.266 & 0.298 & 0.005 & 0.133 & 0.700 \\
\hline $\begin{array}{l}\text { Capitella cf. capitata } \\
\text { (Fabricius, 1780)* }\end{array}$ & 0.078 & 0.119 & 0.046 & 0.060 & 0.302 & Nemertea * & 0.005 & 0.005 & 0.000 & 0.005 & 0.014 \\
\hline Cirratulidae & 0.000 & 0.000 & 0.000 & 0.005 & 0.005 & $\begin{array}{l}\text { Nephtys fluviatilis } \\
\text { (Monro, 1937)* }\end{array}$ & 0.375 & 0.426 & 0.183 & 0.060 & 1.044 \\
\hline Cumacea* & 0.009 & 0.005 & 0.000 & 0.009 & 0.023 & Owenia sp. * & 0.000 & 0.000 & 0.000 & 0.018 & 0.018 \\
\hline Diptera & 0.005 & 0.000 & 0.005 & 0.000 & 0.009 & $\begin{array}{c}\text { Paraprionospio } \\
\text { pinnata (Ehlers, } \\
1901)^{*}\end{array}$ & 0.009 & 0.092 & 0.000 & 0.137 & 0.238 \\
\hline Enteropneusta* & 0.307 & 0.000 & 0.000 & 0.000 & 0.307 & Sabellidae & 0.009 & 0.000 & 0.000 & 0.000 & 0.009 \\
\hline Flabelligeridae & 0.000 & 0.000 & 0.005 & 0.000 & 0.005 & Sigalionidae & 0.000 & 0.000 & 0.005 & 0.000 & 0.005 \\
\hline Gammaridae* & 0.078 & 0.032 & 0.000 & 0.041 & 0.151 & Sigambra sp. * & 0.005 & 0.014 & 0.009 & 0.037 & 0.064 \\
\hline \multirow[t]{2}{*}{$\begin{array}{l}\text { Heleobia australis } \\
\text { (D’Órbigny, 1835)* }\end{array}$} & 24.090 & 21.622 & 16.902 & 26.700 & 89.315 & Syllidae & 0.000 & 0.000 & 0.000 & 0.005 & 0.005 \\
\hline & & & & & & TOTAL & 26.805 & 25.235 & 17.282 & 30.678 & 100 \\
\hline
\end{tabular}

The variables turbidity and temperature had the most weight in the formation of axis 1 , while $\mathrm{pH}$, turbidity and salinity had the strongest weight in the formation of axis 2 (Table 5).

The separation of groups I and II was evident along the horizontal axis, where the elevated turbidity was mostly associated to periods of dredging and to a lesser extent to river discharge above $400 \mathrm{~m} / \mathrm{s}$. The higher temperatures also influenced the increase in species richness and abundance observed in group 2 .

The separation of samples along axis 2 was not quite clear, but it was possible to observe some effect of the ascending salinity, $\mathrm{pH}$, oxygen and temperature in the increased species richness observed at group 2 (Figure 8).

\section{DISCUSSION}

The environmental variables analyzed throughout this study showed constant oscillation and the pattern of variation was slightly distinct when comparing stations 1 and 2 to stations 3 and 4 . The upstream stations 1 and 2 were more influenced by river discharge, probably because they were closer to the Itajai-Mirim river mouth, a smaller tributary on the low estuary. Meanwhile as expected, the downstream stations 3 and 4 had its abiotic variables more affected by dredging, although some effects of it (e.g. higher turbidity) could be observed for stations 1 and 2 , as the tides might have carried the suspended sediment upstream. That observation shows the impact of dredging upon the soft-bottom environment, which presented coarser sediment and higher turbidity during the operations. 

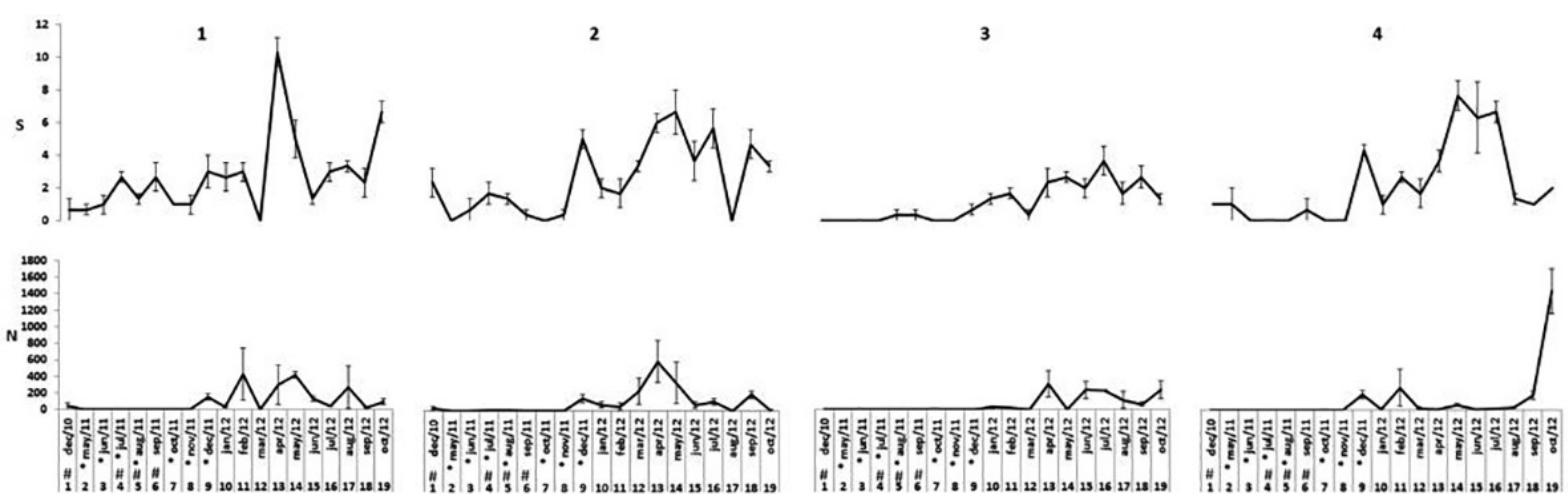

Figure 6. Indicators of Richness (S) and abundance (N) for the macrofauna along the sampling stations (1-4), represented by average per sample $\left(0,042 \mathrm{~m}^{2}\right)$ and standard errors. Stations 1 and 2 were located upstream from the port area and were not dredged while stations 3 and 4 were amidst the dredged area. *indicates capital dredging while \# indicates river discharge above $400 \mathrm{~m}^{3} / \mathrm{s}$.

Table 3. Results of PERMANOVA analysis based on Bray-Curtis similarity matrix, representing all taxa responsible by more than $0,01 \%$ relative abundance. Bold* $\mathrm{p}$ values indicate significant variation.

\begin{tabular}{lccc}
\hline Source of variation & df & F & $p$ \\
\hline Time & 18 & 17.977 & $0.0001 *$ \\
Station & 3 & 9.78 & $0.0001 *$ \\
Time $x$ Station & 54 & 3.5737 & $0.0001^{*}$ \\
Residual & 152 & & \\
Total & 227 & & \\
\hline
\end{tabular}

df: Degrees of freedom.

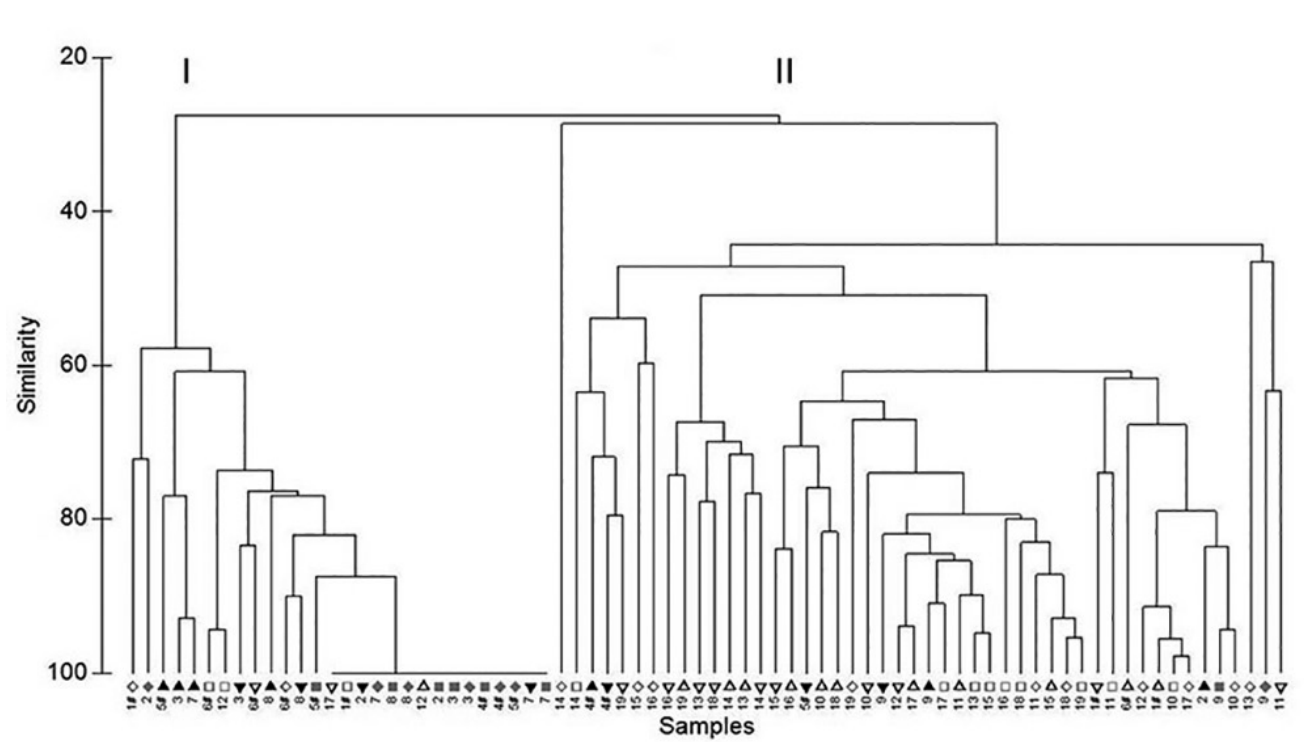

1 Dec/2010
$2 \mathrm{May} / 2011$
$3 \mathrm{Jun} / 2011$
$4 \mathrm{Jul} / 2011$
$5 \mathrm{Aug} / 2011$
$6 \mathrm{Sep} / 2011$
$7 \mathrm{Oct} / 2011$
$8 \mathrm{Nov} / 2011$
$9 \mathrm{Dec} / 2011$
$10 \mathrm{Jan} / 2012$
$11 \mathrm{Feb} / 2012$
$12 \mathrm{Mar} / 2012$
13 Apr/2012
$14 \mathrm{May} / 2012$
15 Jun/2012
$16 \mathrm{Jul} / 2012$
17 Aug/2012
18 Sep/2012
19 Oct/2012
$\Delta$ Station 1-Nondredging
$\nabla$ Station 2-Nondredging
$\square$ Station 3-Nondredging
$\Delta$ Station 4-Nondredging
A Station 1-Dredging
$\nabla$ Station 2-Dredging
Q Station 3-Dredging
Station 4-Dredging

Figure 7. Hierarchical clustering (CLUSTER) based on the Bray-Curtis similarity matrix considering the selected taxa. Stations 1 and 2 were located upstream from the port area and were not dredged while stations 3 and 4 were amidst the dredged area. \#river discharge above $400 \mathrm{~m}^{3} / \mathrm{s}$ and the filled symbols represent the dredging activity.

Our study revealed an assembly composed basically by the polychaetes $H$. similis, $N$. fluviatilis and B. ligerica, the tanaid M. schubarti and the gastropod H. australis. This pattern of few species composing the majority of the benthic assemblages was also observed at other urbanized estuaries in southern Brazil, such as the Patos Lagoon estuary (ROSA; BEMVENUTI, 2006) and at the Paranaguá estuarine complex (SOUZA et al., 2013). Guanabara Bay 
Table 4. SIMPER analysis based on groups (I and II) evidenced in CLUSTER analysis. Av. abundance = average abundance, Av. Diss. = average dissimilarity, Diss. $/ \mathrm{SD}=$ dissimilarity/standard deviation ratio, Cont. $\%=$ percentual contribution for between group dissimilarity, Cum. $\%=$ accumulated percentual contribution for between group dissimilarity.

\begin{tabular}{|c|c|c|c|c|c|c|}
\hline \multirow[b]{2}{*}{ Species } & Group I & Group II & \multirow{2}{*}{ Av. Diss. } & \multirow{2}{*}{ Diss./SD } & \multirow{2}{*}{ Cont. $\%$} & \multirow{2}{*}{ Cum.\% } \\
\hline & \multicolumn{2}{|c|}{ Av. abundance } & & & & \\
\hline H. australis & 0.04 & 3.71 & 53.53 & 2.11 & 56.14 & 56.14 \\
\hline N. fluviatilis & 0.16 & 0.66 & 8.31 & 0.97 & 8.72 & 64.86 \\
\hline H. similis & 0.03 & 0.62 & 7.92 & 0.89 & 8.31 & 73.17 \\
\hline B. ligerica & 0.01 & 0.62 & 5.36 & 0.57 & 5.62 & 78.78 \\
\hline M. shubarti & 0.06 & 0.54 & 5.3 & 0.76 & 5.55 & 84.34 \\
\hline C. capitata & 0.01 & 0.26 & 3.05 & 0.53 & 3.2 & 87.54 \\
\hline A. brasiliana & 0.04 & 0.24 & 2.65 & 0.57 & 2.78 & 90.32 \\
\hline
\end{tabular}

*Average between group dissimilarity $=95.35$

Table 5. Environmental variables and respective correlations to the canonical axis that explained $73 \%$ of the distribution of samples.

\begin{tabular}{lll}
\hline Variable & CAP1 & CAP2 \\
\hline Temp & -0.538 & -0.378 \\
Sal & -0.213 & -0.444 \\
$\mathrm{O} 2$ & -0.285 & -0.291 \\
$\mathrm{pH}$ & -0.038 & -0.544 \\
Turb & 0.743 & -0.498 \\
Mud & -0.176 & 0.178
\end{tabular}

Temp: Temperature, Sal: Salinity, O2: Dissolved oxygen, Turb: Turbidity, Mud: Silt and clay.

in southeast Brazil also showed lower species richness at its inner and more polluted sectors (MENDES et al., 2006; SANTI; TAVARES, 2009; PEREIRA et al., 2013) despite hosting around 300 species benthic macrofauna (SOARESGOMES et al., 2016). Anthropic interventions and natural variability of the ecosystem end up favoring opportunistic and resilient species in the Itajaí-Açu river estuary, and the dominance of only a few species was also observed for the local carcinofauna (LEITE; PEZUTO, 2012).

Opportunistic organisms are conspicuous in estuarine ecosystems, since they are able to quickly colonize postdisturbance environments. Such assemblages tend to be composed by a few dominant species reaching high abundances (PAGLIOSA; BARBOSA, 2006). The most abundant species in our study was $H$. australis of the Hidrobriidae family. It is an epibenthic gastropod, typical in mixohaline environments and able to stand great variations in salinity. Its distribution is associated to muddy-sand substrates, mostly in shallow estuaries (BEMVENUTI, 1987; FRANCESCO; ISLA, 2004).

The dominance of $H$. australis in our study as well as its rapid colonization post dredging corroborates with the

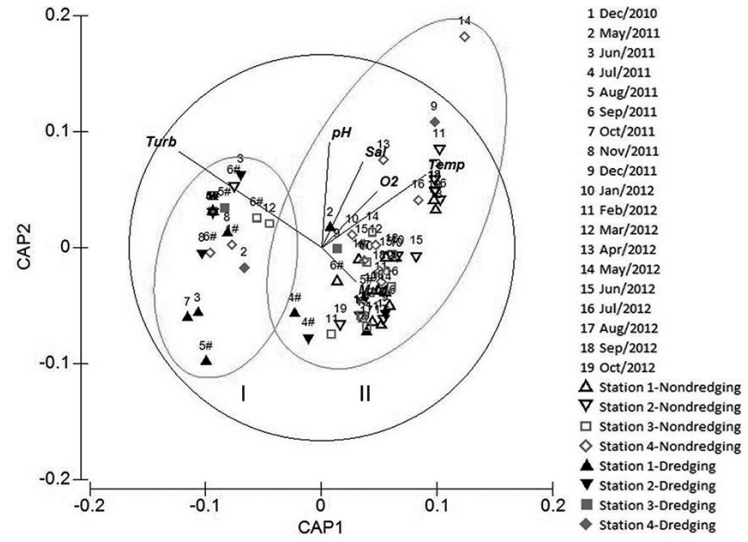

Figure 8. Canonical analysis of Principal Coordinates (CAP). The two first canonical correlations were 0.63 and 0.42 and the canonical axes explained $73 \%$ of the distribution of samples. Turbidity and temperature had the strongest weight in the formation of axis 1 while $\mathrm{pH}$, turbidity and salinity had the strongest weight in the formation of axis 2 . Stations 1 and 2 were located upstream from the port area and were not dredged while stations 3 and 4 were amidst the dredged area. Turb=turbidity, Sal=salinity, Temp=temperature, $\mathrm{Mud}=$ silt and clay, \#=river discharge above $400 \mathrm{~m} 3 / \mathrm{s}$ and the filled symbols represent the dredging activity.

findings of ECHEVERRÍA et al. (2010), which evidenced greater densities of this gastropod at some inner and more degraded areas of the urbanized estuary of Guanabara Bay in Rio de Janeiro, suggesting its tolerance to habitat contamination and hypoxic sediments. $H$. australis is highly mobile, and it is capable of creating a gas bubble inside its shell, which enables it to float away along the currents when facing environmental stresses (e.g. dredging), and to rapidly settle again in less disturbed sites. This behavior helps explaining the proliferation of $H$. australis at our study area.

$H$. australis was also described as the dominant species (reaching 95-99\% of total density) in a harbor at the Patos Lagoon estuarine region of southern Brazil (BEMVENUTI et al., 2005). In the subtropical estuary of Paranaguá Bay, 
the increase in macrofaunal density post disturbances was also a result of a clear increase in the abundances of $H$. australis (EGRES et al., 2012) and in some poluted coastal regions of Uruguay $H$. australis is also the dominant species (VENTURINI et al., 2004).

We found $H$. australis dominant mostly at stations 3 and 4, when the dredging operations were not in place, suggesting its displacement in spite of the operations. Nevertheless the epibenthic habit of $H$. australis apparently made it more vulnerable to elevated river discharge, which apparently carried them away towards the river mouth. The high average dissimilarity and dissimilarity/standard deviation ratio obtained through the SIMPER analysis also made $H$. australis favorable for discriminating impacts of dredging on the Itajaí-Açu river estuary (CLARKE; GORLEY, 2006)

The PERMANOVA evidenced significant alterations in the assembly suggesting it was affected by both the environmental heterogeneity and disturbances occurred through time. Significant difference observed for the interaction of the analyzed factors indicated that many sources of variation influenced the assembly composition and structure (ANDERSON et al., 2008; UNDERWOOD, 2000). The observed high variation in abundances and species richness is a sign of constant environmental stress (WARWICK; CLARKE, 1993).

Research related to the spatial distribution of macrofauna in estuarine areas tends to point out higher abundance and richness towards the maritime region, with an impoverishment of the assemblages related to lower salinity (BEMVENUTI, 1997; BEMVENUTI; NETO, 1998) and higher levels of pollution (MUNIZ et al., 2011). That pattern was observed at Guanabara Bay, where mollusc, polychaete and crustacean assemblages were impoverished at its inner sectors due to organic enrichment and hypoxia coupled with prevailing patterns of circulation (MENDES et al., 2007; SOARES-GOMES et al., 2012; VAN DER VEN et al., 2006). In spite of that we would expect greater abundance and richness of the macrofauna of the Itajaí-Açu estuary at the outer stations 3 and 4, but that pattern was not clear.

The fact that stations 1 and 2 presented the higher indicators of abundance and richness during dredging suggests its impact upon stations 3 and 4 where abundance and richness were considerably lower. Station 3, closest to the port area and about $3 \mathrm{~km}$ from the river mouth, showed the lower values of abundance and richness in our study, suggesting it is the most affected by dredging
(BEMVENUTI et al., 2005). This station was part of the dredged area and the closest to the turning basin where the sediment is constantly being revolved.

However, station 4 (further downstream) showed higher abundance and richness in spite of the disturbances when compared to station 3 , probably because of coarser sediment which favors the recuperation of the assembly (DERNIE et al., 2003). Sediment composition was also responsible for alterations in benthic assemblages in Uruguayan estuaries (GIMENEZ et al., 2014).

Besides dredging, river discharge influenced the structure and composition of the assemblage as we could observe lower abundance and richness in all stations when river discharge was above $400 \mathrm{~m}^{3} / \mathrm{s}$. Higher salinity also appears to have had a positive influence on the assemblage at station 4 .

Research conducted by LEITE and PEZUTO (2012) indicated that the carcinofauna of the Itajaí-Açu river is significantly affected by river discharge. They noticed reduction in species abundance and richness during flood events although the assembly was reestablished a few months after the flood. The same pattern was observed in our study.

Intense river discharge lowers salinity levels and can cause the complete extrusion of the salt wedge from the Itajaí-Açu river estuary (LEITE; PEZUTO, 2012), carrying finer sediment towards the adjacent shelf thus resulting in coarser sediment in the river bed. The greatest abundances in this study were recorded in finer sediment, where $H$. australis prevailed.

The CAP diagram showed that the gain in richness and abundance was significantly related to the increase in salinity and temperature, with low turbidity (river discharge below $400 \mathrm{~m}^{3} / \mathrm{s}^{2}$ and in the absence of dredging). Turbidity was also one of the main driving forces influencing the benthic assemblage of coastal lagoons in Uruguay (MEERHOFF et al., 2013).

Our results pointed that despite the discrete effect of seasonality and salt wedge intrusion upon the assembly, the disturbances caused by floods and dredging operations are the main regulators of it. Impacts associated to dredging were stronger than those caused by river discharge, as we had a depleted assembly during the operations at stations 3 and 4

The impacts related to dredging tend to be more intense as the river channel gets deeper. According to the National Institute of Hydrographic Research-INPH (2012) the silting rate for the low estuary after the capital dredging discussed 
through this study was estimated in $1.3 \times 10^{6} \mathrm{~m}^{3} /$ year. There was an increase in the silting rate after the operations, as the salt wedge remains longer in the estuary thus increasing sediment deposition. The salt wedge could be around $60 \%$ of the time along the year in the port region before the capital dredging of 2011, and after that it remained for about $80 \%$ of the time along the year.

That being said, the deeper the navigational channel gets, the greater effort of maintenance dredging is required to keep the water depth and this could compromise the assembly discussed through this paper, as dredging activity showed itself deleterious for the macrofauna.

We showed through this paper that there is the necessity to continuously monitor the macrofaunal assembly on the Itajaí-Açu river estuary, in order to understand the impacts caused by dredging activities. The present legal mechanisms (CONAMA 454/12) does not describe a protocol for monitoring the macrofaunal assembly of port areas, and a routine should be developed to be added to it.

\section{ACKNOWLEDGMENTS}

The authors are thankful to the Coordenação de Aperfeiçoamento de Pessoal de Nível Superior (CAPES) for financial support and to the Port of Itajaí for the collaboration.

\section{REFERENCES}

ANDERSON, M. J. Permanova: a FORTRAN computer program for permutational multivariate analysis of variance. Auckland: Department of Statistics, University of Auckland, New Zealand, 2005. 24 p.

ANDERSON, M. J.; GORLEY, R. N.; CLARKE, K. R. Permanova + for PRIMER: Guide to software and statistical methods. Auckland: Department of Statistics, University of Auckland, New Zealand, 2008.

BEMVENUTI, C. E. Predation effects on a benthic community in estuarine soft sediments. Atlântica, v. 9, p. 5-32, 1987.

BEMVENUTI, C. E. Trophic structure. In: SEELIGER, U.; ODEBRECHT, C. CASTELlO, L. (Eds.). Subtropical convergence marine ecosystem. The coast and the sea in the warm temperate southwestern Atlantic. Heidelberg: SpringerVerlag, 1997. p. 70-73.

BEMVENUTI, C. E.; NETO, S. Distribution and seasonal patterns of the sublittoral benthic macrofauna of Patos Lagoon (South Brazil). Rev. Bras. Biol., v. 58, n. 2, p. 211-221, 1998.

BEMVENUTI, C. E.; ANGONESI, L. G.; GANDRA, M. S. Effects of dredging operations on soft bottom macrofauna in a harbor in the Patos Lagoon estuarine region of southern Brazil. Braz. J. Biol., v. 65, n. 4, p. 573-581, 2005.

BOLAN, S. G.; REES, H. L. Minimizing impacts of maintenance dredged material disposal in the coastal environment: a habitat approach. Environ. Manage., v. 32, n. 2, p. 171-188, 2003.
BRASIL. INSTITUTO NACIONAL DE PESQUISAS HIDROVIÁRIAS (INPH). Estimativa preliminar da taxa de assoreamento após as obras de ampliação do porto de Itajaí - SC. Brasília: Presidência da Republica, Secretaria Especial de Portos, 2012.

CARVALHO, J. L. B. As dragagens no porte de Itajaí: aspectos econômicos. Dynamis, v. 4, n. 17, p. 76-87, 1996.

CLARKE, K. R.; GORLEY, R. N. PRIMER v6: user manual/ tutorial. Plymouth: PRIMER-E, 2006. 192 p.

COSTANZA, R.; D'ARGE, R.; DE GROOT, R.; FARBER, S.; GRASSO, M.; HANNON, B.; LIMBURG, K.; NAEEM, K.; O'NEILL, R.V.; PARUELO, J.; RASKIN, R. G.; SUTTON, P.; VAN DER BELT, M. The value of the world's ecosystem services and natural capital. Nature, v. 387, p. 253-260, 1997.

COOPER, K. M.; CURTIS, M.; WAN HUSSIM, W. M. R.; BARRIO FROJÁN, C. R. S.; DEFEW, E. C.; NYE, V.; PATERSON, D. M. Implications of dredging induced changes in sediment particle size composition for the structure and function of marine benthic macrofaunal communities. Mar. Pollut. Bull., v. 62, n. 10, p. 2087-2094, 2011.

CRUZ-MOTTA, J. J.; COLLINS, J. Impacts of dredged material disposal on a tropical soft-bottom benthic assemblage. Mar. Pollut.. Bull., v. 48, n. 3-4, p. 270-280, 2004.

DERNIE, K. M.; KAISER, M. J.; WARWICK, R. M. Recovery rates of benthic communities following physical disturbance. J. Anim. Ecol., v. 72, n. 6, p. 1043-1056, 2003.

ECHEVERRÍA, C. A.; NEVES, R. A. F.; PESSOA, L. A.; PAIVA, P. C. Spatial and temporal distribution of the gastropod Heleobia australis in an eutrophic estuarine system suggests a metapopulation dynamics. Nat. Sci., v. 2, n. 8, p. 860-867, 2010.

EGRES, A. G.; MARTINS, C. C.; OLIVEIRA, V. M.; LANA, P. C. Effects of an experimental in situ diesel oil spill on the benthic community of unvegetated tidal flats in a subtropical estuary (Paranaguá Bay, Brazil). Mar. Pollut. Bull., v. 64, n. 12, p. 2681-2691, 2012.

FAUCHAULD, K.; JUMARS, P. A. The diet of worms: A study of polychaete feeding guilds. Oceanogr. Oceanogr. Mar. Biol. Annu. Rev., v. 17, p. 193-285, 1979.

FRANCESCO, C. G.; ISLA, F. I. The life cycle and growth of Heleobia australis (D'orbigny, 1835) and h. conexa (Gaillard, 1974) (gastropoda: rissooidea) in mar Chiquita coastal lagoon (Argentina). J. Molls. Stud., v. 70, n. 2, p. 173-178, 2004.

FRASER, C.; HUTCHINGS, P.; WILLIAMSON, J. Long-term changes in polychaete assemblages of Botany Bay (NSW, Australia) following a dredging event. Mar. Pollut. Bull., v. 52, n. 9, p. 997-1010, 2006.

FREITAS-JÚNIOR, F.; CHRISTOFFERSEN, M. L.; ARAÚJO, J. P.; BRANCO, J. O. Spatiotemporal distribution and population structure of Monokalliapseudes schubarti (Tanaidacea: Kalliapseudidae) in as estuary in Southern Brazil. Sci. World J., v. 2013, p. 1-9, 2013.

GABINETE DO PLANEJAMENTO E COORDENAÇÃO GERAL - GAPLAN. Atlas de Santa Catarina. Rio de Janeiro: Aerofoto Cruzeiro, 1986. 173 p.

GIMENEZ, L.; VENTURINI, N.; KANDRATAVICIUS, N.; HUTTON, M.; LANFRANCONI, A.; RODRÍGUEZ, M.; BRUGNOLI, E.; MUNIZ, P. Macrofaunal patterns and animal-sediment relationships in Uruguayan estuaries and coastal lagoons (Atlantic coast of South America). J. Sea. Res., v. 87, p. 46-55, 2014. 
HARVEY, M.; GAUTHIER, D.; MUNRO, J. Temporal changes in the composition and abundance of the macro-benthic invertebrate communities at dredged material disposal sites in the Anse a Beaufils Bais des Chaleurs, Eastern Canada. Mar. Pullut. Bull., v. 36, n. 1, p. 41-55, 1998.

KENNISH, M. J. Environmental threats and environmental future of estuaries. Environ. Conserv., v. 29, n. 1, p. 78-107, 2002.

LEITE, I. P.; PEZZUTO, P. R. Efeito de um evento extremo de enchente sobre os decápodos infralitorais do estuário do Itajaí-Açu, SC, Brasil. Braz. J. Aquat. Sci. Technol., v. 16, n. 12, p. 13-26, 2012.

MEERHOFF, E; RODRÍGUEZ-GALLEGO, L.; GIMÉNEZ, L.; CONDE, D.; MUNIZ, P. Spatial patterns of macrofaunal community structure in coastal lagoons of Uruguay. Mar. Ecol. Prog. Ser., v. 492, p. 97-110, 2013.

MENDES, C. L. T.; SOARES-GOMES, A.; TAVARES, T. Seasonal and spatial distribution of sublittoral soft-bottom mollusks assemblages at Guanabara Bay, Rio de Janeiro, Brazil. J. Coast. Res., v. 39, p. 1877-1881, 2006.

MENDES, C. L. T.; TAVARES, M.; SOARES-GOMES, A. Taxonomic sufficiency for soft-bottom sublittoral mollusks assemblages in a tropical estuary, Guanabara Bay, Southeast Brazil. Mar. Pollut. Bull., v. 54, n. 4, p. 377-384, 2007.

MUNIZ, P.; VENTURINI, N.; HUTTON, H.; KANDDRATAVICIUS, N.; PITA, A.; BRUGNOLI, E.; BURONE, L.; GARCÍA-RODRÍGUEZ，F. Ecossystem health of Monetevideo coastal zone: a multi approach using some different benthic indicators to improve a ten-year-ago assessment. J. Sea. Res., v. 65, n. 1, p. 38-50, 2011.

NEWELL, R. C.; SEIDERER, L. J.; SIMPSON, N. M.; ROBINSON, J. E. Impacts of marine aggregate dredging on benthic macrofauna off the south coast of the United Kingdom. J. Coast. Res., v. 20, n. 1, p. 115-125, 2004.

PAGLIOSA, P. R.; BARBOSA, F. A. R. Assessing the environment-benthic fauna coupling in protected and urban areas of Southern Brazil. Biol. Conserv., v. 129, n. 3, p. 408417, 2006.

PEREIRA-FILHO, J.; SPILLERE, L. C.; SCHETTINI, C. A. F. Dinâmica de nutrientes na região portuária do estuário do rio Itajaí-Açu, SC. Atlântica, v. 25, n. 1, p. 11-20, 2003.

PEREIRA-FILHO, J.; RÖRIG, L. R.; SCHETTINI, C. A. F.; SOPPA, M. A.; SANTANA, B. L.; SANTOS, J. E. Spatial changes in the water quality of Itajaí-Açu fluvial estuarine system, Santa Catarina, Brazil. An. Acad. Bras. Ciên., v. 83, n. 4, p. 963-982, 2010.

PEREIRA, R. M. F. A. Formação sócio-espacial do litoral de Santa Catarina (Brasil): gênese e transformações recentes. Geosul, v. 18, n. 35, p. 99-129, 2003.

PEREIRA, C. V. P.; PESSOA, L. A.; FREITAS, M. A. V.; ECHEVERRÍA, C. A. Recovery Process on Soft-Bottom Macrobenthic Communities after Artificial Disturbance in Tropical Polluted Estuary (Guanabara Bay, Rio de Janeiro, Brazil). Open J Mar. Sci., v. 3, p. 161-166, 2013.

ROSA, L. C.; BEMVENUTI, C. E. Temporal variability of the estuarine macrofauna of the Patos Lagoon, Brazil. Rev. Biol. Mar. Oceanogr., v. 41, n. 1, p. 1-9, 2006.
SANTI, L.; TAVARES, M. Polychaete assemblage of an impacted estuary, Guanabara Bay, Rio De Janeiro, Brazil. Braz. J. Oceanogr., v. 57, n. 4, p. 287-303, 2009.

SCHETTINI, C. A. F. Caracterização física do estuário do rio Itajaí-açu. Rev. Bras. Rec. Hid., v. 7, n. 1, p. 123-142, 2002.

SKILlETER, G. A.; PRYOR, A.; MILLER, S.; CAMERON, B. Detecting the effects of physical disturbance on benthic assemblages in a subtropical estuary: a beyond BACI approach. J. Exp. Mar. Biol. Ecol., v. 338, n. 2, p. 271-287, 2006.

SOARES-GOMES, A.; MENDES, C. L.T.; TAVARES, M.; SANTI, L. Taxonomic sufficiency of polychaete taxocenes for estuary monitoring. Ecol. Indic., v. 15, n. 1, p. 149-156, 2012.

SOARES-GOMES, A.; GAMA, B. A. P.; BAPTISTA NETO, J. A.; FREIRE, D. G.; CORDEIRO, R. C.; MACHADO, W.; BERNARDES, M. C.; COUTINHO, R.; THOMPSON, F. L.; PEREIRA, R. C. An environmental overview of Guanabara Bay, Rio de Janeiro. Reg. Stud. Mar. Sci., 2016, https://www.researchgate.net/publication/292921881_An environmental_overview_of_Guanabara_Bay_Rio_de_ Janeiro_Regional_Studies_in_Marine_Science.

SOUZA, F. M.; BRAUKO, K. M.; LANA, P. C.; MUNIZ, P.; CAMARGO, M. G. The effect of urban sewage on benthic macrofauna: a multiple spatial scale approach. Mar. Pullut. Bull., v. 67, n. 1-2, p. 234-240, 2013.

STRICKNEY, R. R.; PERLMUTER, D. Impact of intracoastal waterway maintenance dredging on a mud bottom benthos community. Biol. Conserv., v. 7, n. 3, p. 211-225, 1975.

SUGUIO, K. Introdução à sedimentologia. São Paulo: Edgar Blucher, 1973. $317 \mathrm{p}$.

THRUSH, S. F.; DAYTON, P. K. Disturbance to marine benthic habitats by trawling and dredging: Implications for marine biodiversity. Annu. Rev. Ecol. Syst., v. 33, p. 449-473, 2002.

UNDERWOOD, A. J. Importance of experimental design in detecting and measuring stresses in marine populations. J. Aquat. Ecossyst. Stress Recovery, v. 7, n. 1, p. 3-24, 2000.

VAN DER VEN, P. H.; SOARES-GOMES, A.; TAVARES, M. Taxocene of crustacean at a highly impacted bay: Guanabara Bay, southeastern Brazil. J. Coast. Res., v. 39, p. 1135-1139, 2006.

VENTURINI, N.; MUNIZ, P.; RODRÍGUEZ, M. Macrobenthic subtidal communities in relation to sediment pollution: a test of the applicability of the phylum-level meta-analysis approach in a southeastern coastal region of South America. Mar. Biol., v. 144, p. 119-126, 2004.

VIVAN, J. M.; DI DOMENICO, M.; ALMEIDA, T. C. M. Effects of dredged material disposal on the benthic macrofauna near Itajaí Harbor (Santa Catarina, South Brazil). Ecol. Eng., v. 35, n. 10, p. 1435-1443, 2009.

WARE, S.; BOLAM, S. G.; REES, H. L. Impact and recovery associated with the deposition of capital dredgings at UK disposal sites: lessons for future licensing and monitoring. Mar Pollut Bull., v. 60, n. 1, p. 79-90, 2010.

WARWICK, R. M.; CLARKE, K. R. Increased variability as symptom of stress in marine communities. J. Exp. Mar. Biol. Ecol., v. 172, n. 1-2, p. 215-226, 1993. 